\title{
Assessments of the Current Agricultural Extension Systems and Recommended for Interventions in Gurage Zone Ethiopia
}

\author{
Ayalew Adela ${ }^{1} \quad$ Bethel Nekir $^{2}$ \\ 1.Holetta Agricultural Research Center, Ethiopian Institute of Agricultural Research (EIAR), P.O. Box, 2003, \\ A.A, Ethiopia \\ 2.Wolkite Agricultural Research Center, Ethiopian Institute of Agricultural Research (EIAR), P.O. Box, 2003, \\ A.A, Ethiopia
}

\begin{abstract}
This paper anticipated to identifying the existing extension systems, problem unhindered and recommends the interventions which contribute to improve or enhance the extension systems in the study area. From a total of twelve districts in Gurage zone the study covers agro ecologically classified seven districts with a total of twelve villages. FGD (Focus group discussion), key informant, DAs(Development agent), university lecturers and concerned bodies were participated to generate these valuable findings. In Gurage Zone a total of 1070 multidisciplinary professionals extension workers were working with 408 FTCs (Farmers training center) to deliver extension service for a total of 236929 smallholders farmers. Regardless of the significance of FTCs in the provision of extension service, it was observed that they are not functioning at full capacity to deliver the expected service due to a number of constraints such as professional turnover, awareness problem, budget shortage and weak monitoring system, information and skill gap. Our study underline that based on group discussion, personal observation and key informant question confirmed that all FTCs are not actively involved with full capacity and also all smallholder farmers do not participated training which was conducted in FTCs. Our survey results showed that there are a number of constraints affecting the performance of the extension service in the study area major extension and socioeconomic focus have been considered as the constraints which were identified in Gurage zone for possible research and development interventions which are likely to improve smallholder farmers production and productivity.
\end{abstract}

Keywords:Agricultural Extension, Intervention

DOI: $10.7176 / \mathrm{JBAH} / 12-1-01$

Publication date: January $31^{\text {st }} 2022$

\section{Introduction}

\subsection{Agricultural Extension and Socioeconomic perspective}

The development of the Ethiopian economy severely depends upon the speed with which agricultural growth is achieved. The rate of agricultural growth in Ethiopia in turn depends on the speed with which the current existence activity production system is transformed in to knowledge based and market activity production system. Among the many institutional support services that need to catalyze/support the transformation process, the agricultural extension service plays critical role, since it contributes to the development of the skill and knowledge of farmers to adopt new and improved technologies and the approaches and processes with which the skill development and access to information are realized (Birhanu et al., 2006).

Buford (1990), pointed out that 'agricultural extension depends to a large extent on information exchange between and among farmers on the one hand, and a broad range of other actors on the other hand. 'Extension, along with education and research is typically seen as both public and private services, which respond to the needs of farmers and rural people for knowledge that can help to improve their productivity, incomes and welfare, and to manage the natural resources, in a sustainable way. It also brings information and new technologies to the agrarian communities in order to improve their production, incomes and standards of living' (Deribe, 2007).

Available evidences indicate that peasant agriculture in Ethiopia is characterized by subsistence farming system using backward traditional farm tools and farming practices, with low productivity that unable to produce sufficient amount of food for the country's rapidly growing population. Various factors can be cited for slow growth of agriculture such as the trend of conventional farming system as a result of poor extension service coupled with climatic change, reduced soil fertility, recurrent and prolonged drought periods, weak agricultural research base, inadequate financial service, poor infrastructure and market service, environmental degradation (population growth, deforestation, pollution, depletion of ozone layer, destruction of biodiversity, decline of water resources, inappropriate chemical utilization), and fragmentation of land holdings. Furthermore, lack of improved technologies, non participatory training system had been contributed for slow growth of agriculture.

Therefore, in least developed countries like Ethiopia, improving the performance of the agricultural sector is the best alternative to show the way out of poverty and hunger. Though, there is potentially cultivable land in the low lands of the country, high population growth rate makes the expansion of farmland difficult in the high 
lands As a result land size is diminishing from time to time and even there are landless families in the rural Ethiopia. Degradation that results from intensive cultivation, overgrazing, short or zero fallow periods, cultivation of steep slopes, the climate change time to time, the farmers are luck of knowledge, luck of technology demand and supply, participation of women in agricultural activity etc. was observed in the country long time ago. These and many other problems necessitate bringing in the idea of agricultural extension in the county to minimize the gap between the demand and supply of food, to reduce the pressure on the natural resources, and to avert land degradation. Without any doubt, the outward shift in production possibility frontier needs transformation of the agricultural sector by the use of improved agricultural technologies, and interventions like agricultural extension to the rural mass(Wale and Yalew, 2007) by provision of farmers training and advisory services, participatory technology demonstration and promotion using individual and farmers group approaches. In this case, Farmers development group and farmers' Training Centers (FTCs) are widely used for technology demonstrations and promotion while facilitating the provision of extension service to create farmers technology demand.

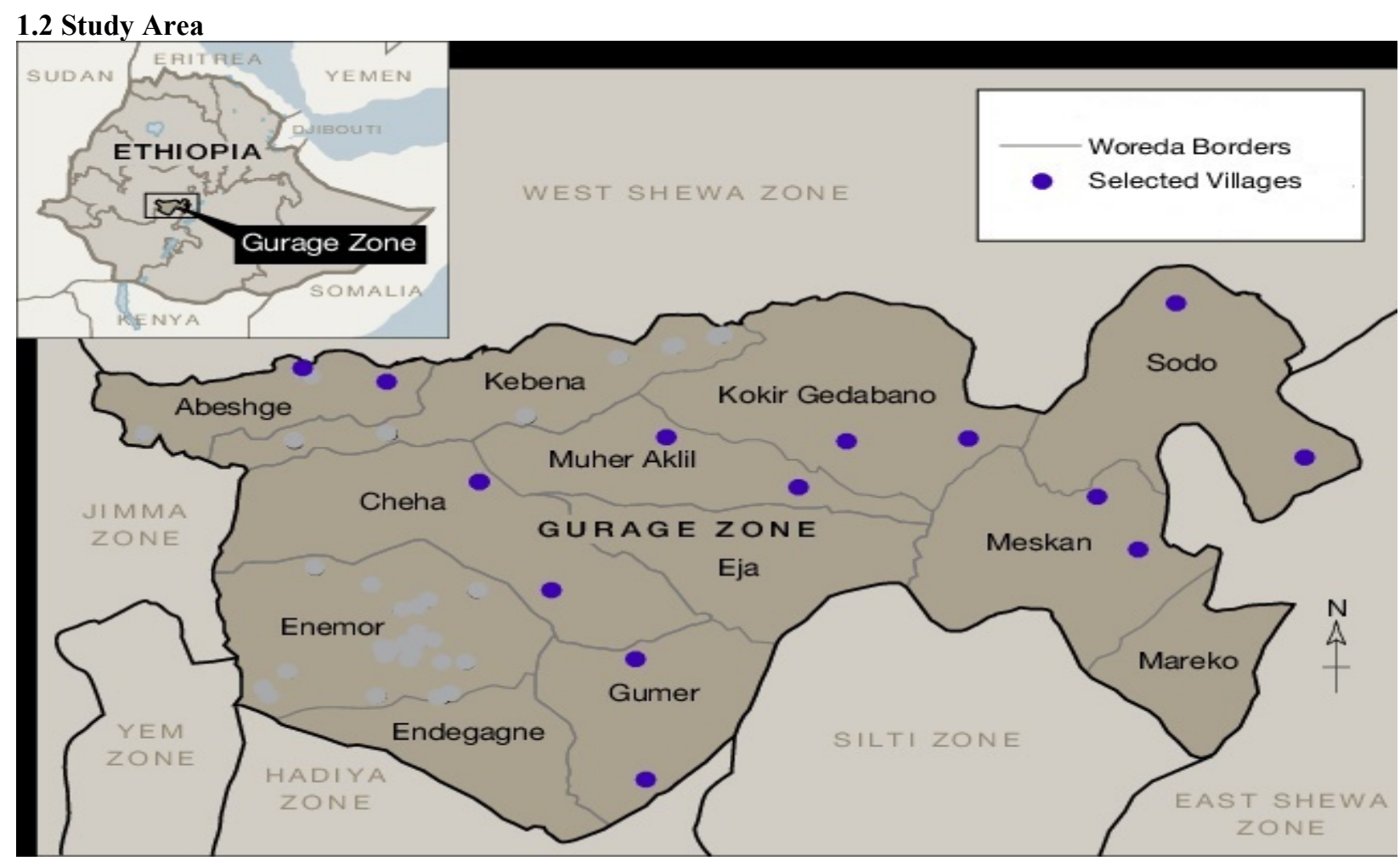

\section{Survey Results}

Currently, the provision of agriculture extension service in Gurage Zone is implemented based on a total of 1070 active extension workers with multidisciplinary professionals working from zone to village level(figure 1) using 408 FTCs and categorized in to advanced, intermediate, basic and pre basic which is based on the standard of service delivery. In all aspects of explanation a total of 236929 smallholders farmers were participated in Gurage zone extension package programs.(figure 2)

Regardless of the significance of FTCs in the provision of extension service, it was observed that they are not functioning at full capacity to deliver the expected service due to a number of constraints such as professional turnover, awareness problem, budget shortage and weak monitoring system, information and skill gap.

Our study underline that based on group discussion, personal observation and key informant question confirmed that all FTCs are not actively involved with full capacity and also all smallholders farmers do not participate training which were conducted in FTCs. 


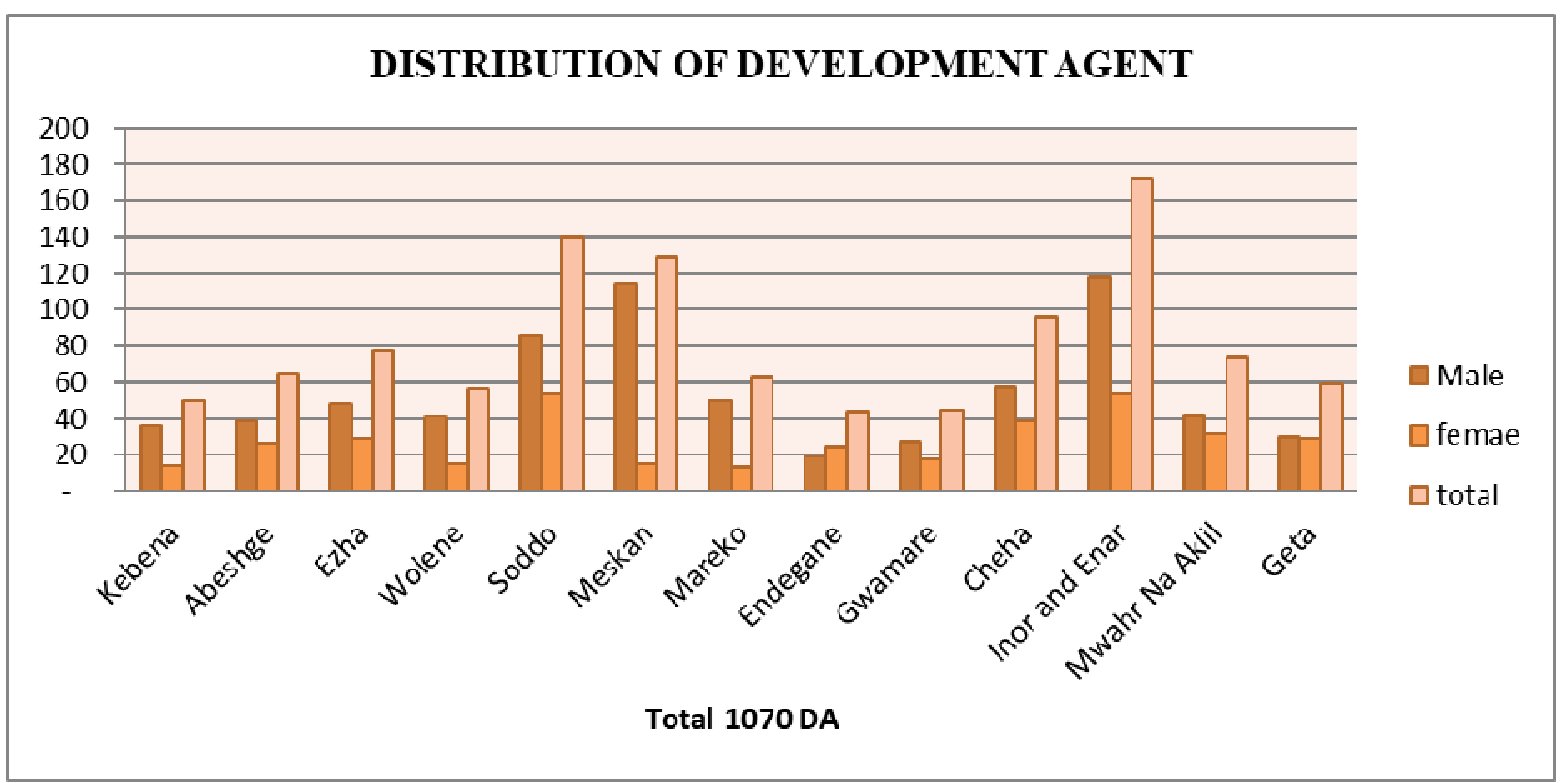

Figure 1 Distribution of development staff in Gurage Zone, 2019

Source: Zone Office of Agriculture, 2019

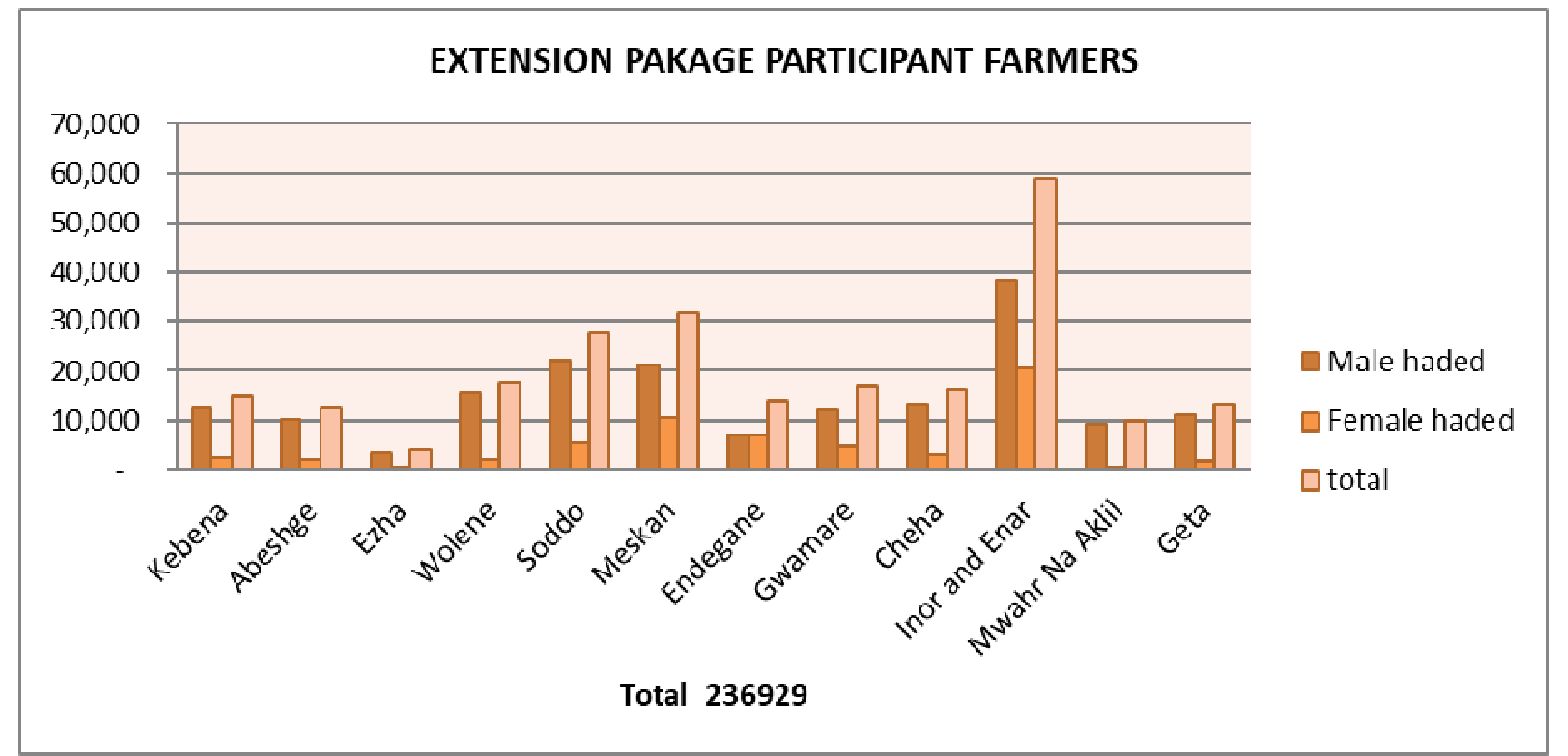

Figure 2 Extension package participant farmers Gurage Zone, 2019

Source: Zone Office of Agriculture, 2019

Our survey results showed that there are a number of constraints affecting the performance of the extension service in Gurage zone as briefly outline as follows:

$>$ FTS are currently not totally functional more of them are in good condition professional turnover, awareness problem, shortage of budget, less attention and weak monitoring systems

$>$ Agricultural extension workers (DAs) are often engaged in extra assignments such as health, tax collection and political party activities. Which is additional work load, time consuming so that extension workers fail to focus on their major responsibility in supporting smallholder farmers

$>$ It was reported that extension workers have information gap which reflected less responsive to emerging concern such as insect and disease pests predicament

$>$ It was reported that there was a technical skill gap and proper planning of extension workers to organize and conduct training for farmers.

$>$ FTS approach more focused on crop production however NRM (Natural resource management), livestock and feed production technologies are neglected.

$>$ Lack of morphology, agronomy and improved processing technology of Enset to scaling -up

$>$ Most of the investigated farmers were not participated training organized in FTC.

$>$ Lack of storage pest control and recommended of postharvest technologies to scaling-up 
$>$ Lack of recently released improved seeds of crop, vegetables (potato) and no improved faba bean and field pea crop introduced

$>$ Decline of crop and potato yield from year to year

\subsection{Agricultural Credit}

Rural financial markets are characterized by asymmetric information (Hoff and Stiglitz, 1993). Lenders do not have full information about the characteristics of borrowers. Financial markets in developing countries face problems of adverse selection, moral hazard and weak enforcement of contracts (Eboh, 2000; Dowd, 1992; Ghosh et al., 2000; Conning and Udry, 2007). Thus, formal financial institutions (banks) are characterized by high costs and lower interest rates (Hoff and Stiglitz, 1990), and are often inadequate in supply (Chaudhuri and Gupta, 1996). They discriminate against the poor and women (Ray, 1998), and exhibit delayed disbursement of loans (Sarap, 1990; Hoff and Stiglitz, 1990). This has led to the search for alternative financial service delivery systems for the poor so as to help them get out of poverty (Krahnen and Schmidt, 1994; Nguyen, 2007).

As in the case of other developing countries, although the potential demand for small loans is tremendous in Ethiopia, the formal banking sector in the country is less interested in providing financial services to smallholder farmers (Amha, 2004).Wealth indicators such as farm size and labor endowment increased the probability of a smallholder farmer's participation in the agricultural credit market and suggest focusing on wealth creation schemes and/or poverty reducing schemes for the area. Gender is an important factor influencing participation in microfinance programs.

Poor farmers in developing countries often lack the financial resources to make the necessary investments in agriculture (Komicha and Ohlmer, 2006; Ageba, 1998). The formal financial services provided by banks are less accessible to poor farmers in rural areas because the poor in rural areas lack collateral (supply-side constraint), their loan size demands are small (demand-side constraint),

Agricultural credit constraint is believed to influence agricultural production and improving financial services to the poor enhances agricultural productivity through facilitating adoption of yield improving agricultural technologies (Ellis, 2000; Blancard et al., 2006; Petrick, 2005; Barry and Robinson, 2001; Bose, 1998; Alene and Hassan, 2006). There is a wider agreement that increased technology adoption has the potential to contribute to economic growth and poverty alleviation among the smallholder farmers in developing countries, particularly in sub-Saharan Africa. However, it has been widely documented that lack of capital or liquidity constraints are the major barriers for smallholder farmers to adopt agricultural technologies that could improve their productivity and increase farm income.

Our survey results showed that the principal source of credit for smallholder farmers in Gurage zone is omo microfinance. But small holder farmers don't want to get credit from micro finance high interest rate, very long and boring process and not easily assessable at village or kebele level religious Muslim farmers want to get loan without interest payment but microfinance not allowed. in group discussion all participant farmers agreed that there is no credited institutions specially works for small holder farmers before year of 2018 provision of agricultural input credit mainly fertilizer were given to farmers but starting 2019 year this provision were stopped small holder farmers forced to by fertilizer on cash this implies that farmer due to shortage of money cannot used the recommended fertilizer rate which resulted low crop yield in Gurage zone our group discussion and key informant question agreed that most of the farmers participated in our study were very interested in cash credit but there has been a wider complaint that awareness and accessibility of credit institutions at grass root level in Gurage zone were a critical problem. The following several limitations were identified in related to credit provision to small holder farmers.

$>$ Lacks inventive credit provision service. In this case, Micro finance does not address smallholders farmers credit demand on individual basis rather credit is extended on group basis serving as a group guarantor.

$>$ Poor farmers in Gurage zone lack the financial resources to make the necessary investments in agriculture. The formal financial services provided by banks are less accessible to resource poor farmers lack of collateral (supply-side constraint).

$>$ Agricultural credit constraint is believed to influence agricultural production and improving financial services to the poor smallholders farmers which enhances agricultural productivity through facilitating adoption of yield improving and recommended agricultural technologies in Gurage zone..

\subsection{In-puts}

Ethiopia presents one of the most important global challenges in agricultural development. Accordingly, the Government of Ethiopia has consistently emphasized agricultural productivity growth and food security in its long-term development strategies. Over the past two decades, decision makers in Ethiopia have pursued a range of policies and investments to boost agricultural production and productivity, particularly with respect to the food staple crops that are critical to reducing poverty in the country. A central aim of this process has been to 
increase the availability of improved seed, chemical fertilizers, and extension services for small-scale, resourcepoor farmers, particularly those cultivating food staple crops. While there is some evidence to suggest that the process has led to improvements in both output and yields during this period, decision makers still recognize that there is extensive room for improvement.

Despite successful field demonstrations and several policy level interventions since the late 1980s, it is only recently that fertilizer consumption has begun to increase sharply. While consumption has in fact tripled in the past decade, it is still far behind other African and fast developing countries of the world. The national average fertilizer consumption remains at $23.8 \mathrm{~kg} / \mathrm{ha}$, in contrast to a $62.0 \mathrm{~kg} / \mathrm{ha}$ world average, $39.4 \mathrm{~kg} / \mathrm{ha}$ in $\mathrm{Ghana}$, 141.3 in South Africa and 181.7 in Brazil. Improving the supply system that enables fabricated fertilizers to reach end users will also require due attention. Thus, a multi-channeled fertilizer supply system is planned for creation in order to address smallholder farmer needs on time, at affordable prices and at the required location.

Fertilizer remains a considered agricultural input to increase the productivity of smallholder farmers under the obvious problem of soil fertility depletion. There have been several efforts in the past including provision of credit facilities to encourage the wider adoption of fertilizer technology by smallholder farmers.

The consumption of fertilizer in Gurage zone has been increasing significantly since recent years. As clearly point out that in 1016,2017,2018 and 2019 cropping seasons for irrigation, Belge and main season Gurage zone were used 197124,223637,236266 and 208348 quintals of different fertilizers as an inputs(figure 3). The major commercial fertilizer types commonly used in Gurage zone are urea, NPSB, NPS, NPSZn, NPSBCu, urea and potassium. This fertilizer formulation has been developed based on the Ethio SIS soil map of Gurage zone .Until 2014/2015 cropping season, DAP and Urea were used to be the sole commercial fertilizers applied in Ethiopia .Currently, urea and NPSB are the most widely used fertilizer types in zone small holder farmers(figure 4)

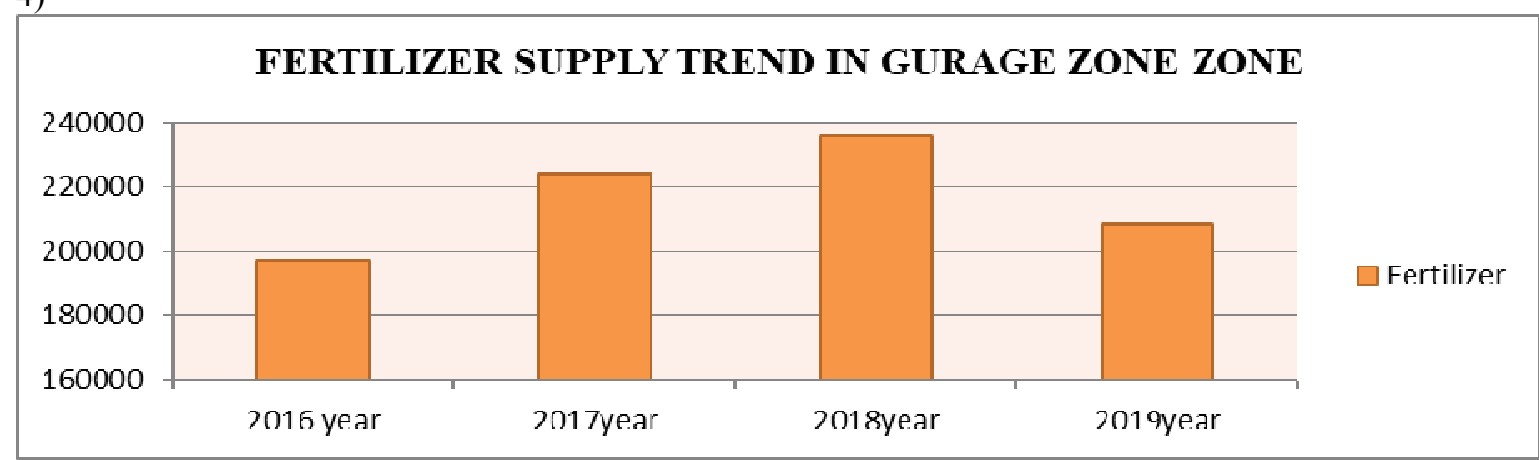

Figure 3. Trend of fertilizer consumption in Gurage zone (2019)

Source: Zone Office of Agriculture, 2019

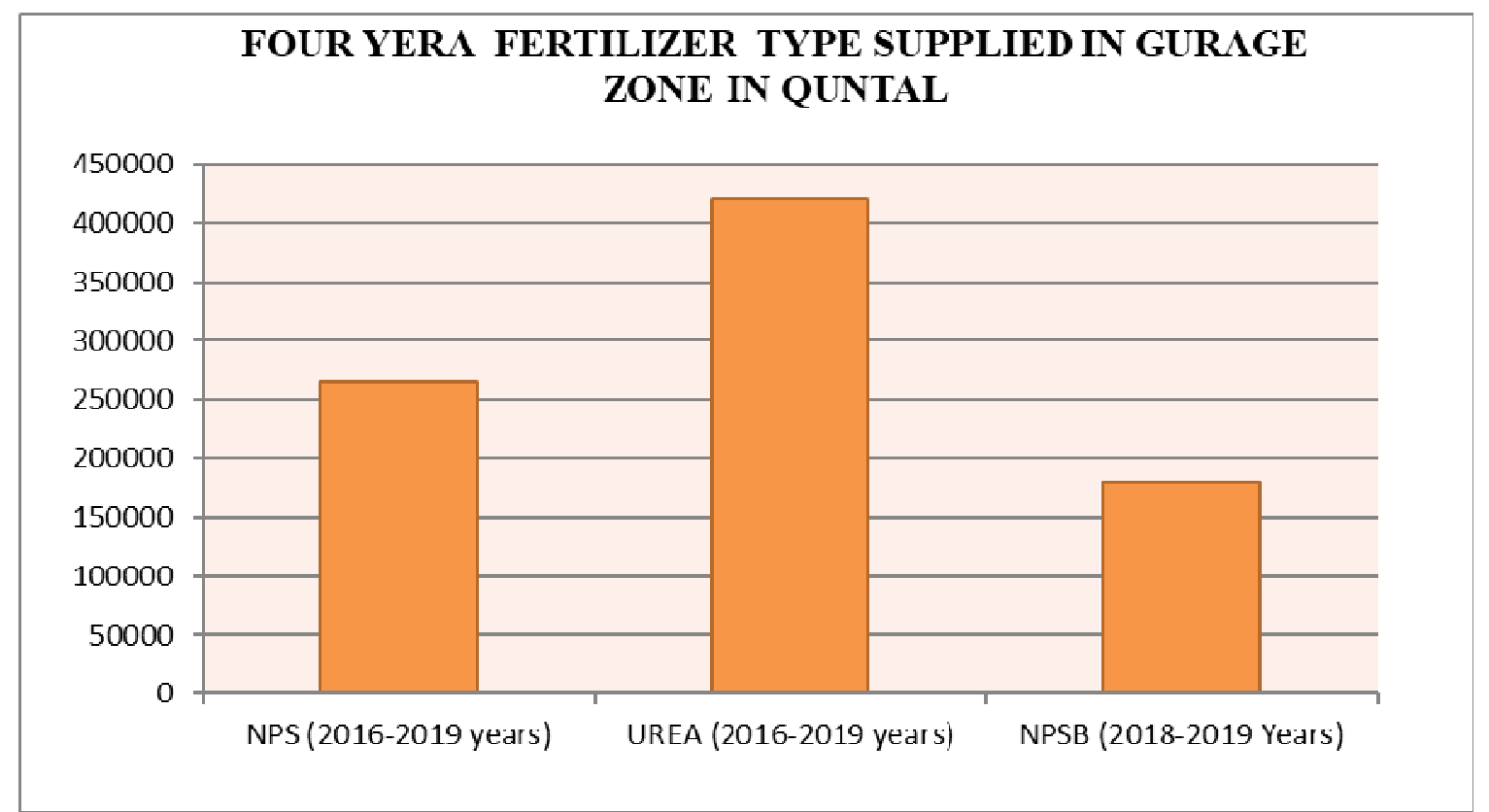

Figure 4. Fertilizer type supplied in Gurage zone (2019)

Source: Zone Office of Agriculture, 2019 
FCUs(Farmers co - operative union) are the major actors in the distribution of fertilizer in Gurage Zone. There are totally four FCUs in the Gurage zone, namely Admas, Waleta, Temerte and Edeget which are actively engaged in the distribution of commercial fertilizer together public once to smallholder farmers in their respective area. It was also indicated that fertilizer distribution is commonly based on cash transaction starting from 2018/2019 there is no credit and percentage down payment in Gurage zone.

There has been an increasing demand of improved seeds in Gurage Zone. The distribution of improved seeds is guided through the regional extension and input supply system involving FCUs. Except for hybrid maize and potato the major sources of improved seeds like barely, wheat and tef are exclusively from the public seed enterprise such as ESE (Ethiopian Seed enterprise) and SSE(south seed enterprise). The private sector is actively engaged in hybrid maize seed and informal potato seed production and distribution. Regarding to crop protection technology herbicide, insecticide and fungicide smallholder farmers have no accesses in Gurage zone there is no enough public and accessible private suppliers.

Our survey results of key informant questions and FGDs with farmers as briefly discussed that smallholder farmers in Gurage zone have no accesses to get recent year realized crop varieties. The following outlined major agricultural input supply and consumption constraints were identified.

$>$ Ever-increasing of fertilizer price is not affordable to smallholder farmers in zone

$>$ Smallholder farmers not apply the recommended amount of fertilizer per hectare

$>$ Break off credit supply of fertilizer to smallholder farmers.

$>$ Unpredictable and insufficient precipitation is major problem in fertilizer application in moisture stress lowland areas of the zone.

$>$ Seed quality problem, low germination and presence of mixed seeds(off type)

$>$ supply of varieties not well-suited with the expected local weather conditions not the interest of individual farmers(Limited options for seed sources)

$>$ only concentrated on improved cereals (barely, tef, wheat and maize(from private producer)

No or shortage of improved leguminous crop like faba bean, field pea and chick pea

$>$ No recently released improved crop varieties available to smallholder farmers (out dated potato varieties )

$>$ No supply of agro chemicals (herbicide, insecticide and fungicides etc.) public in Gurage zone

\subsection{Mechanization and farm machinery rental services}

Farm mechanization seems to have become to a certain extent the neglected soul of agricultural and rural development. As an essential input, mechanization can transform farm family economies by facilitating increased output and reducing the drudgery of hand-powered production. Mechanization, when carefully selected and appropriate to the task, is also capable of protecting natural capital and the environment whilst boosting food production.

When looking at the resources required for increased and sustained agricultural production (land, water and farm power for mechanization) it is clear that Africa has comparatively the most abundant land resources; however, the continent has the lowest farm power base with less than 10 percent of mechanization services provided by engine-powered sources. At the same time approximately 25 percent of farm power is provided by draught animals and over 70 percent comes from people's muscles (mostly from women, the elderly and children). This human power source often only has rudimentary tools and equipment at its disposal for soil preparation, crop care, transport of goods and bucket irrigation.

Agriculture is mostly smallholder based where about $90 \%$ of the farmers own less or equal to two ha per household. In addition to human muscle, in most cases and particularly in cereal based systems, oxen-draft is the main source of farm power for land preparation and planting. In agro forestry systems, where hand-hoe is the dominant farm implement, human muscles are used for all farm operations. In wheat-based systems of some highlands regions, wheat harvesting and threshing are mainly done using combine harvesters. Smallholder farmers in these areas are relatively better in terms of agricultural mechanization level.

While Gurage zone is characterized as a high potential area in agricultural production, it was observed that the use of mechanization in terms of improved machineries and farm implements is still not there. This has brought about high workload on oxen and human labor, and postharvest problems in terms of yield and quality loss and also row planting could only be practical when suitable row planter is introduced. Broadcast sowing has serious limitations on productivity. The row planter machine minimizes the time to be spent in manual row planting and increase competence decrease seed rate and improve crop yield.

Smallholder farmers have practiced the benefit of manual row planting of maize and potato, in Gurage zone where as for tef, wheat and barley farmers are also interested in sowing seeds in row, but manual row planting is very laborious compared to other large seeded cereals. As a result, in most of study area in zone smallholder farmers are still remains usually planted with broadcast method due to the nonexistence of improved farm machines or tools that could be used for row planting.

In the study area key informant survey and FGDs participant farmers were agree that in Gurage zone there 
is no attention for improved simple farm machinery for plowing, planting, chemical spraying, harvesting and threshing in most of zone area plowing still done by hoeing(dig) of human muscle, the cost of labor for plowing, harvesting is getting very expensive and plowing and threshing by cattle has become very difficult due to the decreasing number of livestock associated with deficiency of feed and decrease grazing lands. Hence in all study area, farmers show very great interest and aware the use of machines for plowing, planting, harvesting and threshing their crops have been progressively growing.

The processing methods of Enset is traditionally a role for women, who act as a reservoir of knowledge about the processing techniques involved, but the tasks involved are labor-intensive, tedious and primitive way of processing all Gurage zone farmers specially womens demanding processing machinery is number one priority.

Thus, the introduction and demonstration of agricultural machineries for plowing, planting, harvesting, threshing and Enset processing will have great implication in increasing the efficiency, success of farming activities and food security at household level.

\subsection{Access to Markets}

The rural population in Gurage zone is dependent on agriculture, making agricultural support and development to their livelihoods which make agricultural development a top government priority in the region as well as in Gurage zone. It is not possible to visualize the transformation of agriculture from subsistence to market-oriented production in the absence of infrastructure development like road. The development of road infrastructure gets better accessibility and mobility of farm input and outputs while improve the whole of agricultural production and encourage further investment. Especially it is the major driving factor for improving the efficiency of agricultural inputs and outputs markets which creating motivation for increasing the adoption of improved agricultural technologies. Our group discussion and personal observation agreed that some progresses of road infrastructure development in Gurage zone rural village roads which create more accesses to market all participant smallholder farmers agreed that there is no problem of access to market for their products.

\subsection{The seed system}

Generally, the seed system in the Gurage zone is characterized by both formal and informal seed systems where the majority of the farming community exercised informal seed systems in the zone.

The formal seed system involves the distribution of seeds of improved varieties through the regular extension program which developed at the local (kebele) level and then transmitted through official channels to the zonal and regional levels, after which they are aggregated Zonal level to produce estimates of the type and quantity (but not preferences for specific varieties or traits) of seed that needs to be supplied from Zone seed enterprise to zone via to farmers through Cooperatives and unions based on input supply schemes.

It was indicated that the major seed producer enterprises currently active in the seed market include SSE, ESE, and private seed producer. However, significant to note that the private sector in the Gurage zone is active in the hybrid maize and in some part of zone very few farmers involves on improved potato seed production this empowering of farmers through the production of improved potato seed were supported by Holeta agricultural research center.

But it was observed by our study that there were no community-based seed production systems such as improved seed producers groups which possibly will be an option to the formal improved seed sources. This obviously demonstrated that there was a very weak linkage gap between agricultural research and extension part from zone agricultural office in empowering smallholder farmers with improved seed production management skills including the provision of source seeds.

Our survey results also observed that there is no significant extension approach of seed revolving mechanism in Gurage zone which helps to equip and support smallholder farmers to have their own improved seed with contravention of long improved new seed provision system and also help farmers do not have an option of gaining improved seed through conventional way.

Our survey results showed that the formal seed system is restricted to the delivery of a small number of crops mainly barley, wheat, maize, and tef while other important cereals, food legumes, and puls crops remain marginal.

The largest informal seed system involves mainly seed exchange among farmers and seed revolving practices. It is the major source of seeds for most crops that are not produced by the formal seed system such as food legumes and some cereals. The informal seed system currently remains the most viable option in sustaining the production system by enabling smallholder farmers to have access to seeds of the required quantity on time and space.

The other informal seed system involves seed exchange among farmers. In this case, the seed exchange involves seeds of a given crop with a similar crop, for example, tef with tef, or other different crops, like barely with wheat depending on their agreement. However, the seed exchange is not at random rather farmers use seed 
exchange with other farmers whom they know very well in good seed management in their community

In general, Gurage zone agricultural office should be given attention to the following remarks

$>$ Lack of alternative community-based seed production system such improved seed producer group or cooperatives

$>$ Increasing seed price most of the smallholder farmers in the Gurage zone improved seed price has been increasing tremendously which cannot affordable for smallholder farmers.

$>$ Lack of alternative seed sources for food legumes such as faba bean. field pea others

$>$ Lack of awareness of smallholders farmers about improved seeds management, handling, Poor storage facilities and capacity of farmers' cooperative and unions

$>$ Lack of attention to take Enset in the formal or informal seed multiplication system compare to cereals and root crops like potato .

\section{Cause-effect Analysis of Farming Systems Problems and socio-economic Problems}

Major socioeconomic limitation in the farming systems of Gurage zone from our Group discussion key informant interview ,desk review and field personal observation an attempt was also made to provide causeeffect analysis of those limitations representative major causes, effects, possible interventions and opportunities presented to improve farm production and productivity. The socioeconomic limitation include agricultural extension, credit, inputs supply, access to markets, farm machinery rental services, land fragmentation and declining farm size.

3.1 Cause-effect analysis of major Agricultural Extension and Socioeconomic problems

\begin{tabular}{|c|c|c|c|c|}
\hline Problem & cause & effect & interventions & stakeholders \\
\hline $\begin{array}{l}\text { High input costs } \\
\text { Fertilizer } \\
\quad \text { Improved seeds }\end{array}$ & $\begin{array}{ll}* & \text { No } \\
\text { competitive } & \\
\text { input } \\
* \quad \text { only public } \\
\text { input supplier }\end{array}$ & $\begin{array}{l}\text { No need use of } \\
\text { inputs } \\
\text { Decline } \\
\text { productivity } \\
\text { less adoption of } \\
\text { improved } \\
\text { agricultural } \\
\text { technologies }\end{array}$ & $\begin{array}{l}\text { Improve \& Strength } \\
\text { agricultural credit } \\
\text { system } \\
\text { Accessible input } \\
\text { market at weread } \\
\text { level } \\
\text { * Formal and informal } \\
\text { seed Multiplication } \\
\text { - Support to Promotion } \\
\text { and distribution of } \\
\text { Improved } \\
\text { Agricultural Inputs } \\
\text { Farmers } \\
\text { operative and unions } \\
\text { Capacity Building } \\
\text { Establishment and } \\
\text { strengthening of } \\
\text { Community Based } \\
\text { Seeds and forage } \\
\text { production groups }\end{array}$ & $\begin{array}{l}\text { RBOA(regional biro of } \\
\text { agri,) } \\
\text { ZBOA(zone biro of } \\
\text { agri) EIAR(Ethiopian } \\
\text { Inst. Agri Rese) } \\
\text { SARI(South } \\
\text { Agri.Rese.Insti), } \\
\text { SSI(south seed Inter.) } \\
\text { UNVERSITY } \\
\text { NGOs }\end{array}$ \\
\hline $\begin{array}{l}\text { Accesses to agro } \\
\text { chemicals } \\
\text { Herbicides } \\
\text { Insecticides } \\
\text { Fungicides }\end{array}$ & * Not available & $\begin{array}{ll} & \text { Decline } \\
& \text { productivity } \\
\text { crop devastation }\end{array}$ & $\begin{array}{l}\text { *ncouraging } \\
\text { participation of privet } \\
\text { suppliers } \\
\text { supply through } \\
\text { farmers cooperatives } \\
\text { and unions Capacity } \\
\text { Building } \\
\text { build up efficient } \\
\text { demand and supply } \\
\text { analysis strategies } \\
\text { Support to Promotion } \\
\text { and distribution of } \\
\text { Improved } \\
\text { Agricultural Inputs }\end{array}$ & $\begin{array}{l}\text { RBOA ,ZBOA } \\
\text { EIAR,SARI } \\
\text { MICROFINANCE } \\
\text { Private Suppliers }\end{array}$ \\
\hline
\end{tabular}




\begin{tabular}{|c|c|c|c|c|}
\hline Problem & cause & effect & interventions & stakeholders \\
\hline $\begin{array}{l}\text { Accesses to } \\
\text { newly realized } \\
\text { crop and } \\
\text { livestock } \\
\text { technologies }\end{array}$ & Not introduce & $\begin{array}{l}\text { use out-of-date } \\
\text { varieties } \\
\text { * yield reduction } \\
\text { Susceptible and } \\
\text { attack by } \\
\text { diseases, insect } \\
\text { and pest }\end{array}$ & $\begin{array}{l}\text { Generate enabling } \\
\text { environment for on } \\
\text { farm variety } \\
\text { adaptation trails } \\
\text { * Promote large scale } \\
\text { seed multiplication } \\
\text { on farmers plots } \\
\text { improve FTC's } \\
\text { management } \\
\text { Pre-extension } \\
\text { Demonstration and } \\
\text { Participatory } \\
\text { Research } \\
\text { Establishment and } \\
\text { strengthening of } \\
\text { Farmers Research } \\
\text { and Extension } \\
\text { Groups (FREGs) }\end{array}$ & $\begin{array}{l}\text { EIAR ,SARI, ZBOA } \\
\text { RBOA,UNVERSITY } \\
\text { NGOs, SSI }\end{array}$ \\
\hline $\begin{array}{l}\text { Access to } \\
\text { agricultural } \\
\text { credit services }\end{array}$ & $\begin{array}{l}\text { *ack of credit } \\
\text { provision } \\
\text { Religiously } \\
\text { not accepted } \\
\text { loan interest } \\
\text { group } \\
\text { approach for } \\
\text { credit } \\
\text { collateral } \\
\text { Lack of } \\
\text { awareness } \\
\text { about credit } \\
\text { institution } \\
\end{array}$ & $\begin{array}{l}\text { Too less } \\
\text { demand credit } \\
\text { * } \\
\text { ret use } \\
\text { recommended } \\
\text { rate of inputs } \\
\text { * less investment } \\
\text { less improved } \\
\text { input use } \\
\text { Declining } \\
\text { productivity } \\
\end{array}$ & $\begin{array}{l}\text { * create awareness of } \\
\text { credit provision } \\
\text { Make sure accessible } \\
\text { of credit provision } \\
\text { near to users } \\
\text { plan to considered } \\
\text { individual loan } \\
\text { provision rather } \\
\text { group loan } \\
\text { considered interest } \\
\text { free loan for muslim } \\
\text { religious believers } \\
\end{array}$ & $\begin{array}{l}\text { Micro-finance, FCUs, } \\
\text { ZBOA,NGOs }\end{array}$ \\
\hline $\begin{array}{ll}\text { *ccess } & \text { to } \\
\text { information } & \\
\text { about } & \\
\text { agricultural } & \\
\text { technologies } & \end{array}$ & No awareness & $\begin{array}{l}\text { Ignorance for } \\
\text { improved } \\
\text { agricultural } \\
\text { technologies } \\
\text { No demand for } \\
\text { improved } \\
\text { technologies } \\
\text { Limits } \\
\text { opportunity for } \\
\text { research centers } \\
\text { some trainings, } \\
\text { adaptation and } \\
\text { demo trials }\end{array}$ & 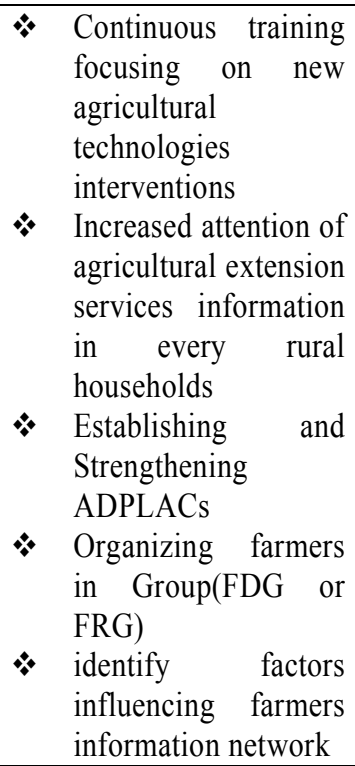 & $\begin{array}{l}\text { EIAR,SARI, } \\
\text { UNIVERSITY } \\
\text { ZBOA,NGOs }\end{array}$ \\
\hline
\end{tabular}




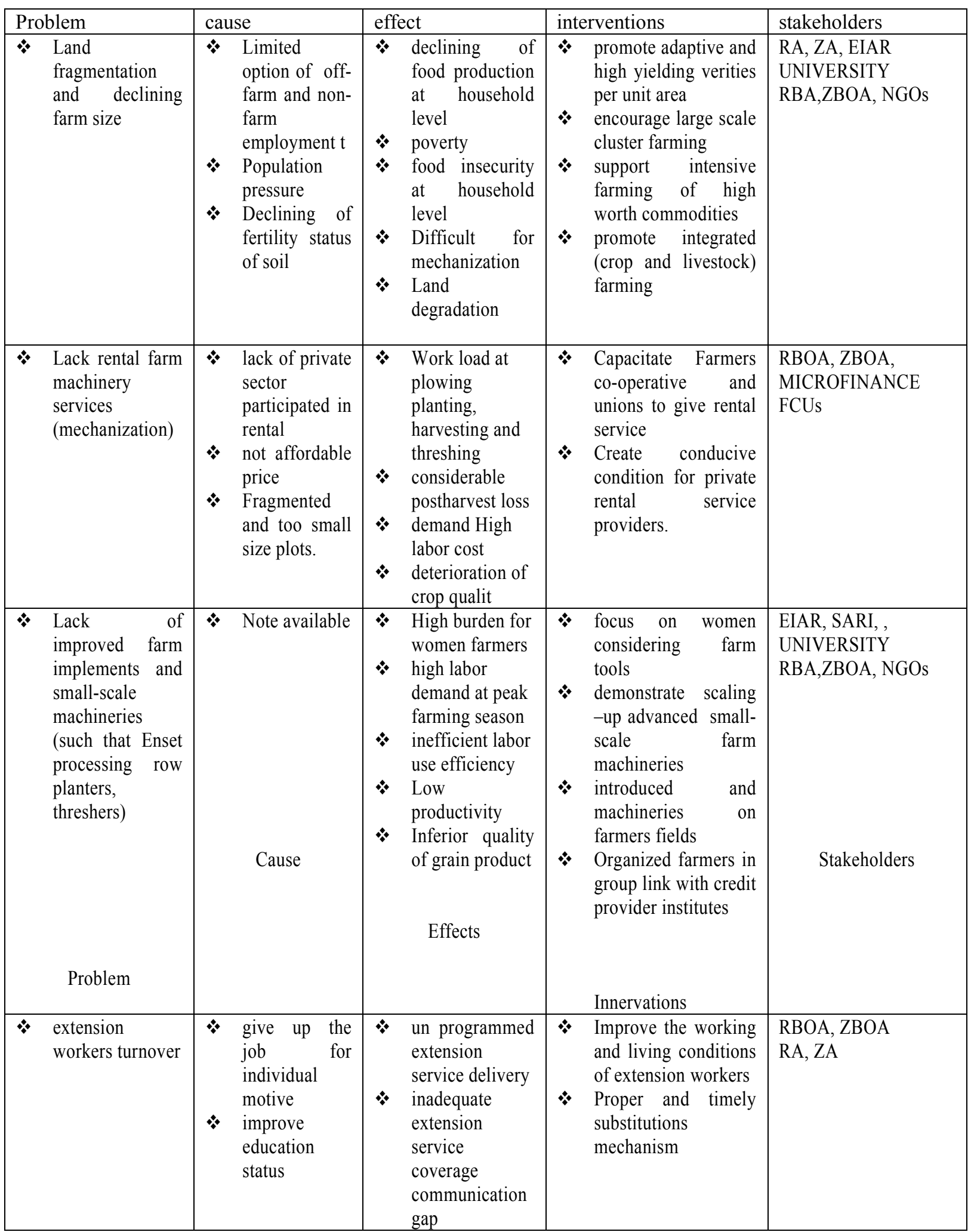




\begin{tabular}{|c|c|c|c|c|}
\hline Problem & cause & effect & interventions & stakeholders \\
\hline $\begin{array}{l}\text { Linkage between } \\
\text { agricultural } \\
\text { research and } \\
\text { extension }\end{array}$ & $\begin{array}{l}\text { Weak } \\
\text { awareness } \\
\text { No forum to } \\
\text { plan,monitori } \\
\text { ng and } \\
\text { evaluation at } \\
\text { grass root } \\
\text { level }\end{array}$ & $\begin{array}{l}\text { exposed to } \\
\text { insubstantial } \\
\text { information } \\
\text { Individual } \\
\text { knowledge } \\
\text { based decision } \\
\text { No } \\
\text { Ccollaborations } \\
\text { and exchange of } \\
\text { useful } \\
\text { information } \\
\text { No technology } \\
\text { generation, } \\
\text { dissemination } \\
\text { and utilization } \\
\text { system. } \\
\text { No stakeholder } \\
\text { meeting } \\
\text { Discourage } \\
\text { group work }\end{array}$ & $\begin{array}{l}\text { * Create a chance for } \\
\text { agricultural research } \\
\text { provide new realizing } \\
\text { technologies } \\
\text { Promote } \\
\text { ccollaborations and } \\
\text { exchange of useful } \\
\text { information among } \\
\text { all actors of the } \\
\text { technology } \\
\text { generation } \\
\text { dissemination and } \\
\text { utilization system. } \\
\text { Established platform } \\
\text { joint planning } \\
\text { evaluating and } \\
\text { monitoring } \\
\text { Demonstration of } \\
\text { improved agricultural } \\
\text { technologies }\end{array}$ & $\begin{array}{l}\text { EIAR,SARI, } \\
\text { UNCERSITY } \\
\text { ZBOA }\end{array}$ \\
\hline $\begin{array}{l}\text { women's access } \\
\text { to extension and } \\
\text { credit services }\end{array}$ & $\begin{array}{l}\text { No attention } \\
\text { assuming } \\
\text { economically } \\
\text { inactive }\end{array}$ & $\begin{array}{l}\text { Ignore } \\
\text { significant } \\
\text { contribution to } \\
\text { agriculture } \\
\text { Ignore ensuring } \\
\text { food security at } \\
\text { household level } \\
\text { Ignoring the } \\
\text { mainstay of the } \\
\text { farm labor. }\end{array}$ & $\begin{array}{l}\text { Promote extension } \\
\text { training for women } \\
\text { Empowering women } \\
\text { by availing } \\
\text { technologies } \\
\text { supported with credit } \\
\text { scheme. } \\
\text { Organized women in } \\
\text { groups and } \\
\text { introducing } \\
\text { homesteads farming. }\end{array}$ & $\begin{array}{l}\text { EIAR,SARI, } \\
\text { UNCERSITY } \\
\text { ZBOA } \\
\text { WAO }\end{array}$ \\
\hline
\end{tabular}

\section{Projected interventions to major extension and socioeconomic constraints}

The following major extension and socioeconomic focus have been considered as the constraints which were identified in Gurage zone for possible research and development interventions which are likely to improve smallholders farmers production and productivity.

3.1 Unaffordable agricultural inputs (improved seeds, fertilizers) cost for smallholder farmers have been constrained to improve their productivity

\subsubsection{Proposed interventions:}

* Improve and Strength the capacity agricultural in puts credit institutions and farmers co-operatives and unions.

* Considering operation cost of farm inputs minimization which directly influence the cost of inputs

* Accessible agricultural in puts market and micro finance credit institutions for smallholder farmers at wereda or kebele level

* set up and promote formal and informal community based seed Multiplication systems by providing improved seeds, technical advice and training

* Introducing and encourage private improved seed producer.

* scaling up large scale cluster improved seed crop production

* Encourage farmers working in a group to produce improved seed which helps smallholders farmers will have better access to seeds 
4. No or inadequate supply of agro chemical farm inputs (herbicide, insecticide and fungicide) not use crop protection technologies result total crop damaged or yield loss

4.1 Proposed interventions:

* Develop and promote the participation of private suppliers in agro chemicals markets Improve the capacity of FCUs in the inputs markets through technical and finance support;

* Farmers co-operatives and unions be supposed to focus on supplies agro chemicals to smallholder farmers.

* Build up periodical demand and supply analysis will be conduct.

5. Limited accesses to newly realized crop and livestock technologies farmers were forced to use long period of year ago realized crop verities.

5.1Proposed interventions:

* Build a two way communication with Agricultural research centers and stakeholders

* Generate enabling environment by introducing and evaluating newly realized technologies

* promote Large scale cluster improved seed multiplication on farmers plots

* Organize and conducted farmers skill improvement training programs

6. Lack of access to agricultural credit which implies resource poor farmers reduce adoption of improved agricultural technologies

6.1Proposed interventions:

* Make sure that smallholders farmers have access to credit provision close to users

* Works on farmers knowledge regarding agricultural credit provision

* plan to considered individual loan provision rather group loan approach

* considered interest free loan for Muslim religious believers which is not allowed by sherea lows

* Policy makers should take an action by reinforces farmers co-operative and unions to serve as agricultural credit institution.

7. Lack of access to information regarding improved agricultural technologies which implies ignorance and no demand for improved agricultural technologies

7.1Proposed interventions:

* Promote continuous theoretical and practical trainings focusing on new agricultural technologies interventions

* Create awareness of improved agricultural technologies through different extension tools like radio, TV, brochure etc

* Promote platform group like (FDG or FRG(Farmers research Group)) for further discussion and information exchange

* Identify factors which render farmers information network

8. Land fragmentation, decreasing farm size, declining fertility status of soil, population pressure and limited option of non-farm employment which lead to food insecurity at household level

8.1Proposed interventions:

* Introducing and promoting adaptive high yielding verities per small plot area

* conducting large scale cluster farming

* promoting intensive farming of high worth commodities

* Encouraging smallholder farmers exercising integrated (crop and livestock) farming

9. Lack of rental farm machinery services (mechanization)

9.1Proposed interventions:

* Capacitate Farmers co-operative and unions to give rental farm machinery service

* Create conducive condition for private rental service providers.

* promote motivation mechanisms for the private sector to engage in the farm machinery rental service

10. Lack of improved farm implements and small-scale machineries (such that Enset processing, row planters, threshers etc) increasing competence and productivity

10.1Proposed interventions:

* introducing women serving improved agricultural technologies farm tools

* Scaling - up improved and adaptive small-scale farm machineries and implements

* introduced and demonstrate simple improved agricultural machineries on farmers fields

* Organized farmers in group and link with credit provider institutes

* Support the development of standards mechanization technologies 
11. Extension workers turnover resulted un programmed extension service delivery and inadequate extension service coverage communication gap

11.1Proposed interventions:

* Improve the working and living conditions of extension workers

* Develop Proper and timely substitutions mechanism which avoid delaines of extension activities

\section{Linkage between agricultural research and extension}

12.1Proposed interventions:

* strengthening platforms like ADPLAC(Agricultural Development Partners Linkage Advisory Council) and create a chance for grassroots level participate in the platform to jointly planning evaluating and monitoring

* Promote ccollaborations and exchange of useful information among all actors of the technology generation dissemination and utilization system.

* Demonstration of improved agricultural technologies

* promote and create a chance for agricultural research centers to provide newly realized technologies

13. No Access of women to extension and credit services which ignored significant and mainstay contribution of the farm labor of agriculture and ensuring food security at household level

13.1Proposed interventions:

* Promote extension training for women

* Empowering women by availing improved agricultural technologies and credit provision.

* Organized women in a groups and promoting integrated homesteads farming.

\section{Conclusion}

Even with its predominantly favorable agro ecology along with great development efforts in the past, the production and productivity of agriculture sector in Gurage zone remains under expectations. a number of socioeconomic and biophysical limitation point to the vicious challenges of low productivity and natural resource degradation. The socioeconomic constraints are more generic across commodities having a great impact on technology transfer and adoption process. Availability of improved agricultural technologies is generally inadequate where technology dissemination is limited to a very few major cereal crops. Moreover, high input costs including shortage and late delivery of inputs are the major factors hindering technology adoption by smallholder farmers in Gurage zone. Other support services such as the provision of agricultural extension is characterized by limited performance in creating awareness and technology demand creation among the smallholder farmers community.

Therefore, Agricultural researchers, universities, NGOs and all development interventions in those areas should focus primarily to find the solution of Ensete ventricosum crop problem to realize food shortage by in improving agricultural production and productivity in gurage zone.

\section{Reference}

Amha, W. (2004), "Managing growth of microfinance institutions: balancing sustainability and reaching large number of clients in Ethiopia", Ethiopian Journal of Economics, Vol. 13 No. 2, pp. 61-101.

Birhan Gebramedhin, Hoekstra.D and Azage Tegegne 2006. Commercialization of Ethiopian agriculture: Extension Service from input supplier to knowledge broker and facilitator. IPMS of Ethiopian Farmers Project Working paper ILRI, Nairobi. 33pp.

Buford, J.A. 1990. Extension management in the information age. Journal of Extension, 28(1). Retrieved 15 July, 2006 from http://www.joe.org/joe/1990spring/fut2.html

Chaudhri, S. and Gupta, M.R. (1996), "Delayed formal credit, bribing and the informal credit market in agriculture: theoretical analysis", Journal of Development Economics, Vol. 51 No. 2, pp. 433-49.

Conning, J. (1999), “Outreach, sustainability and leverage in monitored and peer-monitored lending”, Journal of Development Economics, Vol. 60, pp. 51-77.

Deribe (2007),Focusing Agricultural research to Address Development Direction for Agricultural Research in Ethiopia

Dowd, K. (1992), “Optimal financial contracts”, Oxford Economic Papers, Vol. 44 No. 1992, pp. 672-93

Eboh, E.C. (2000), "Rural informal savings and credit associations as risk managers and the lessons for the design and execution of rural credit schemes in Nigeria", African Development Review, Vol. 12 No. 2, pp. 233-60

Ellis, F. (2000), Peasant Economics: Farm Households and Agrarian Development, Cambridge University Press, Cambridge.

Evidence from rural Vietnam”, Edinburgh discussion paper 2007/03, Centre for Economic Reform and 
Transformation, School of Management and Languages, HeriotWatt University, Edinburgh

Ghosh, P., Mookherjee, D. and Ray, D. (2000), "Credit rationing in developing countries: an overview of the theory", in Mookherjee, D. and Ray, D. (Eds), Readings in the Theory of Economic Development, Blackwell, Malden, MA, pp. 283-301

Hoff, K. and Stiglitz, J.E. (1990), "Imperfect information and rural credit markets: puzzles and policy perspectives", The World Bank Economic Review, Vol. 4 No. 3, pp. 235-51.

Hoff, K.and Stiglitz, J. (1993), "Imperfect information and rural credit markets:puzzles and policy perspectives", in Hoff, K., Braverman, A. and Stiglitz, A. (Eds), The Economics of Rural Organization, World Bank, Oxford University Press, Oxford, pp. 406-35.

Komicha, H.H. and Ohlmer, B. (2006), "Effect of credit constraint on production efficiency of farm households in southeastern Ethiopia”, Ethiopian Journal of Economics, Vol. 15 No. 19, pp. 1-33

Krahnen, J.P. and Schmidt, R.H. (1994), Development Finance as Institution Building, Westview Press, Boulder, $\mathrm{CO}$.

Nguyen, C.H. (2007), "Determinants of credit participation and its impact on household consumption:.

Ray, D. (1998), Development Economics, Princeton University Press, Princeton, NJ.

Sarap, K. (1990), "Factors affecting small farmers' access to institutional credit in rural Orissa, India", Development \& Change, Vol. 21 No. 2, pp. 281-307.

Wale, E. and Yalew, A. 2007. Farmers' Variety Attribute Preferences: Implication for Breeding Priority Settings and Agricultural Extension Policy in Ethiopia. African Development Bank, 379-396 